\title{
o3-Tuvacada ad öbeklerinin söz dizimsel işlevleri
}

Uğur ALTUNDAŞ1

APA: Altundaş, U. (2020). Tuvacada ad öbeklerinin söz dizimsel işlevleri. RumeliDE Dil ve Edebiyat Araştırmaları Dergisi, (Ö8), 39-53. DOI: 10.29000/rumelide.814070.

\section{Öz}

Türkiye’de söz öbeklerinin belirlenmesinde kimi zaman öbeğin ana unsuru kimi zaman da yardımcı unsur esas alınmıştır. Bu durum alanyazında birbirinden farklı türde ve sayıda öbek türünün tanımlanmasına sebep olmuştur. Bu sebeple çalışmada söz öbekleri dil bilim kuramlarından hareketle Evrensel dil bilgisi bakış açısıyla ele alınacaktır. Evrensel dil bilgisi terimi, bu çalışmada söz öbeklerine dil bilimsel bakış açısıyla yaklaşan tüm kuramlar kapsamında değerlendirilecektir. Evrensel dil bilgisinde söz öbeklerinin iki temel ögesi bulunmaktadır: baş (head) ve tümleç (complement). Söz öbeklerinin bu iki ögesi arasında yönetim ilişkisi vardır. Baş öge yöneten, tümleç ise yönetilen unsur olarak ele alınmaktadır. Evrensel dil bilgisi, söz öbeklerini baş ögenin sözcük türüne göre adlandırır. Böylece öbeğin baş ögesinin ad, sıfat, zarf, ilgeç veya eylem olma durumuna göre ad öbeği (AÖ), sıfat öbeği (SÖ), zarf öbeği (ZÖ), ilgeç öbeği (İÖ) ve eylem öbeği (EÖ) olmak üzere beş söz öbeği türü tanımlanır. Bu sınıflandırma, sözlüksel kategorilere dayanmaktadır. Bununla birlikte kimi dil bilim kuramları, söz konusu söz öbeklerinin diğer öbek türleriyle olan ilişkisine odaklanır. İşlevsel dil bilgisi, söz öbeklerini bu ilişkilere dayanan işlevler açısından değerlendirir. Söz dizimsel işlevler, bunlardan bir tanesidir. Söz dizimsel işlevler temelde öbeklerin eylemle olan ilişkisini yansıtır ve alanyazında özne, nesne, yüklem vb. şekillerde ele alınır. Bu çalışmada Tuvacada AÖ’ler söz dizimsel işlevler açısından değerlendirilecektir. Söz dizimsel işlevler ögelerin birbirleriyle olan ilişkileri ile ilgilidir. Bu ilişkiye dayanan anlamsal roller, yüklem ile diğer ögeler arasındaki bağı kuran durum ekleriyle sağlanır. Böylelikle Tuvaca AÖ’lerin hangi biçim bilgisel düzeylerde tümcede hangi söz dizimsel işlevleri karşılayabildiği ortaya konulacaktır.

Anahtar kelimeler: Tuvaca, söz öbekleri, evrensel dil bilgisi, işlevsel dil bilgisi, söz dizimsel işlevler

\section{Syntactic functions of noun phrases in Tuvan}

\begin{abstract}
Phrases in Turkey are determined as based on either of the main elements of phrases or ancillary elements. This situation has led to the definition of different types and numbers of phrases in the literature. For this reason, in the study, phrases will be discussed from the perspective of Universal Grammar with linguistic theories. The term Universal Grammar will be evaluated within the scope of all theories that approach phrases from a linguistic perspective. Phrases in Universal Grammar have two basic elements: the head and the complement. There is a management relationship between these two elements of phrases. The main element is considered as the governor, and the complement as the managed element. Universal Grammar calls phrases according to the word type of the head element. Thus, depending on whether the main element of the phrase is a noun,
\end{abstract}

Arș. Gör., Hacettepe Üniversitesi, Edebiyat Fakültesi, Türk Dili ve Edebiyatı Bölümü / Sosyal Bilimler Enstitüsü, Türk Dili ABD (Ankara, Türkiye), ualtundas@gmail.com, ORCID ID: oooo-00o2-7762-0211 [Makale kayit tarihi: 07.09.2020-kabul tarihi: 20.11.2020; DOI: 10.29000/rumelide.814070

Adres

Osmanağa Mahallesi, Mürver Çiçeği Sokak, No: 14/8 Kadıköy / Istanbul / TÜRKIYE

e-posta: editor@rumelide.com

+90 (505) 7958124 / +90 (216) 7730616
Address

Osmanağa Mahallesi, Mürver Çiç̧eği Sokak, No: 14/8

Kadıköy / Istanbul / TURKEY

e-mail: editor@rumelide.com

+90 (505) 7958124 / +90 (216) 7730616 
adjective, adverb, postposition and verb, five types of phrases are defined: noun phrase (NP), adjective phrase (AdjP), adverbial phrase (AÖ), postpositional phrase (PP) and verb phrase (VP). This classification is based on lexical categories. However, some linguistic theories focus on the relationship of these phrases with other types of phrases. Functional grammar evaluates phrases in terms of functions based on these relationships. Syntactic functions are one of them. Syntactic functions basically reflect the relationship between phrases and verbs. And in the literatüre, these relationships are discussed in different ways such as subject, object, and predicate. In this study, NP's in Tuvan will be evaluated in terms of syntactic functions. Syntactic functions are related to the relations of constituents with each other. Semantic roles based on this relationship are provided by case sufffixes that establish the link between predicate and other elements. In this way, it will be revealed Thus, the effects of morphological structures on syntactic functions in Tuvan noun phrases will be revealed.

Keywords: Tuvan, phrases, universal grammar, functional grammar, syntactic functions

\section{Giriş}

Türkiye'de yapılan çalışmalarda söz öbekleri, genel olarak birden fazla sözcüğün bir araya gelerek anlamca ve yapıca bir bütün oluşturduğu söz birlikleri şeklinde tanımlanmıştır. Öbekleri meydana getiren sözcüklerin nasıl bir araya geldikleri konusunda ise farklı görüşler bulunmaktadır. Geleneksel dil bilgisinde söz dizimi alanının içerisinde yer alan öbek yapıların kuruluşu, sözcüklerin dizilişi ile açıklanmaya çalışılmıştır. Buna göre Türkçenin genel diziliş ilkesine uygun olarak söz öbekleri, yardımcı ögenin asıl ögeden önce gelmesiyle oluşmaktadır (Gökdayı 2018: 65). Geleneksel dil bilgisinde öbek yapıların oluşumu, genellikle bu şekilde açılanmıştır. Son yıllarda Türkçenin söz dizimi üzerine yapılan çalışmalarda bu açıklama belirli bir düzene girmiş (Delice 2003; Usta 2009) ve söz öbeklerinin oluşumu temelde aşă̆ıdaki şekillerde ele alınmıştır (Aktan 2016):

\section{Yardımcı unsur + Esas Unsur}

\section{Esas Unsur + Yardımcı Unsur}

\section{Birinci Unsur + İkinci Unsur}

\section{Birinci Unsur + ek + İkinci Unsur}

Araştırmacıların görüşleri arasında kimi küçük farklılıklar bulunsa da öbeklerin oluşumu konusunda temel çıkış noktası, asıl öge ile yardımcı ögenin konumu olmuştur. Söz öbeklerinin adlandırılması ve türlerinin belirlenmesinde ise kimi zaman ana unsur, kimi zaman yardımcı unsur ve kimi zaman da öbeğin aldığı ekler esas alınmıştır. Bu durum, alanyazında birbirinden farklı türde ve sayıda öbek türünün ortaya çlkmasına sebep olmuştur. Bu sebeple bu çalışmada söz öbekleri, dil bilim kuramlarından hareketle Evrensel dil bilgisi bakış açısıyla ele alınmıştır. Evrensel dil bilgisi terimi, genellikle Chomsky'nin 1957'den itibaren ortaya attığı dil bilim kuramları için kullanılır. Bu çalışmada ise söz öbeklerine dil bilimsel bakış açısıyla yaklaşan tüm kuramlar, bu kapsamda değerlendirilmiştir.

Chomsky, Üretken Dönüşümlü Dil bilgisi kuramında dil bilgisinin öbek yapı kurallarından oluştuğunu, öbek yapı gramerinin ise yeniden yazma kurallarıyla (rewritting rules) belirlendiğini ifade etmektedir (1965: 67). Yeniden yazma kuralları, bir anlamda bir öbek yapının üyelerine bölümlenmesidir. Chomsky, bu durum için ayrıştırma (parsing) terimini kullanmaktadır (2002: 26). Sonuç olarak;

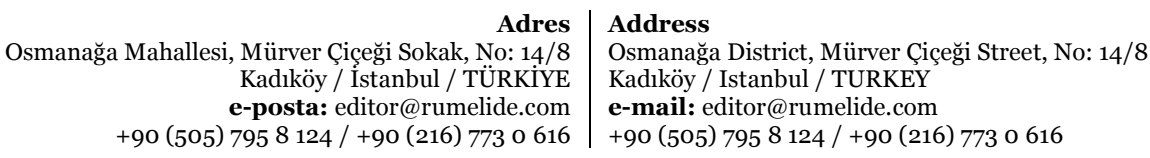


yeniden yazma kuralları ve ayrıştırma işlemleri, bir öbek yapının üyelerinin belirlenmesini ifade etmektedir. Evrensel dil bilgisine göre öbek yapıların iki temel üyesi bulunmaktadır. Bunlar baş ve tümleç olarak adlandırllan üyelerdir. Hangi üyenin baş, hangi üyenin tümleç olduğunu ise Chomsky, 1980’de ileri sürdüğü İlkeler ve Değiştirgenler Kuramı’nın temelini oluşturan Yönetim ve Bağlama teorisi ile belirlemiştir. Yönetim ve Bağlama kuramı, yönetim kavramı üzerine geliştirilmiştir. Bu anlamda bir tümce, ilk olarak eylemin yönetiminde kurulan bir EÖ'den (eylem öbeği) oluşmaktadır. Buna göre bir öbeğin baş ögesi, aynı zamanda öbeğin üyeleri arasında yönetici konumda bulunan üyesidir. Yönetilen öge ise öbeğin tümleci konumunda yer alan üyesidir. Yönetim kuramı, yöneten baş öge ile yönetilen tümleç ögeleri arasındaki ilişkiyi ele almaktadır (1988: 163). İlkeler ve Değiştirgenler Kuramı, yönetim kuramı ile birlikte rol kuramı, durum kuramı gibi farklı alt kuramları içermektedir. Temelde tüm alt kuramlar, yönetim kavramılla ilişkilidir. Yönetim ilişkisi içerisinde bir öbek yapıda yöneten unsur konumundaki baş öge, tümlecine çeşitli anlamsal roller ve durum gibi birtakım özellikler yüklemektedir. Bu durum, öbeğin baş ögesinin yankategorileme çerçevesi kavramıyla açıklanmaktadır. Yankategorileme, bir sözlüksel birimin söz dizimsel yapıda birlikte görüneceği diğer kategorilere ilişkin seçimini ifade eder (Uzun 2000: 97). Bir başka deyişle yankategorileme, bir sözcüğün sözlüksel kütüğünde yer alan ve öbek oluşturmak için yanında hangi üyeyi almak zorunda olduğuna ilişkin bilgi olarak açılanabilir (Özsoy, Balcı ve Turan 2012: 143). Bu bağlamda, yankategorileme çerçevesinde sözlükçeden öbek yapıya doğru bir oluşum söz konusudur. Dolayısıyla yankategorileme, bir anlamda öbek yapı oluşumunu sağlamaktadır (Chomsky 1988: 29).

Öbek yapılarda en önemli unsur, baş denilen ögedir. Yönetim kapasitesine sahip baş öge, öbek yapıların kurucusudur. Türkçe öbek yapılarda baş, her zaman sağ taraftadır. Evrensel dil bilgisine göre bir öbek yalnız bir öge veya farklı söz dizimsel öneme sahip birden fazla ögeden oluşabilir (Turan ve Durmuşoğlu Köse 2012: 35). Tek bir sözcüğün öbek yapı olarak kabul edilmesinde temel sebep, o sözcüğün yönetim çerçevesine sahip olmasıdır. Yani, yalın durumdaki sözcük, bir başka ögeyi yönetebilme kapasitesine sahiptir. Böylelikle yalın durumdaki sözcük, birden fazla sözcükten oluşan bir öbek yapıya dönüşebilmektedir (Kerimoğlu 2017: 76). Türkçe söz öbekleri baş’n sözcük türüne göre sınıflandırılmaktadır. Bir başka deyişle baş olan unsurun sözcük türü ne ise öbeğin türü de odur. Evrensel dil bilgisinde öbeğin türünü, öbek yapının yönetici unsuru konumunda yer alan baş ögenin sözlüksel kategorisi yani sözcük türü belirlemektedir. Bu durumda öbeğin baş ögesinin ad, sifat, zarf, ilgeç veya eylem olma durumuna göre ad öbeği (AÖ), sıfat öbeği (SÖ), zarf öbeği (ZÖ), ilgeç öbeği (İ̈) ve eylem öbeği (EÖ) olmak üzere beş söz öbeği türü bulunmaktadır. Söz öbekleri, dil bilimsel kuramlar bağlamında ele alındığında batı ve Türkiye alanyazınında temelde bu beş başlık altında incelenmektedir. Farklı söz dizimi kuramlarının söz öbeklerine yaklaşımı konusunda detaylı bilgi için Hirik'in Söz Dizimi Kuramları Bağlamında Türkçede Baş Unsur (2020) adlı çalışmasından yararlanılabilir. Dil bilim kuramlarını söz öbeklerini temelde sözlüksel kategorilere göre sınıflandırdığı görülmektedir. Kuramlar arasındaki farklılık, söz öbeklerinin sınıflandırılması üzerinde değil daha çok işlevleri üzerinde görülmektedir. Bu çalışmada Tuvacada AÖ’lerin söz dizimsel işlevleri, söz dizimi kuramları bağlamında incelenmiştir. Çalışmanın veri tabanını, Tuvacanın edebiyat dilini yansıtan roman ve hikâyelerin yanı sıra günümüzde konuşulan Tuvacanın en temel kaynakları arasında yer alan Tuvaca ders kitapları ile Tuvaca araştırmalarının en önemli kaynaklarından Monguş’un iki ciltlik Tıva Dıldı̋ Tayılbırlıg Slovarı “Tuva Dilinin Açıklamalı Sözlüğü" adlı Tuvacadan Tuvacaya örnekli Tuvaca sözlüğ̈̈ oluşturmaktadır. 


\section{Tuvacada ad öbekleri}

Söz dizimsel işlevlere değinmeden önce kısaca bir AÖ yapısından söz etmek gerekir. Öncelikle bir öbeğin AÖ olabilmesi için baş ögenin ad türünde bir sözcük olması gerekmektedir. Evrensel dil bilgisi zamir türünde sözcükleri de ad olarak kabul etmektedir. Bu sebeple baş ögesi zamir olan öbek yapılar da bir AÖ olarak değerlendirilmektedir. Bu durumda bir AÖ’nün baş ögesi konumunda ad ve zamir türünde sözcükler bulunabilir. AÖ’nün tümleci konumuna ise üç farklı sözcük türü gelebilmektedir: ad, sıfat ve belirleyici (determiner). Buna göre Türkçede bir AÖ, $a d+a d$, sıfat $+a d$ ve belirleyici $+a d$ yapılarında karşımıza çıkmaktadır.

Ad + ad yapısındaki AÖ'ler Türkiye Türkçesinde olduğu gibi biçim bilgisel olarak iki şekilde görülmektedir. Birincisinde öbek yapının her iki ögesi de ek almaktadır. Bu durumda öbeğin baş ögesi iyelik ekli, tümleç ögesi ise ilgi durum ekli görülmektedir. Tuvacada iyelik ekleri, kişilere göre sırasıyla şu şekildedir: 1 . tekil kişi: $+(X) m$, 2. tekil kişi: $+(X) \eta$, 3. tekil kişi: $+z X /+X$, 1. çokluk kişi: $+v X s, 2$. çokluk kişi: $+\eta A r$, 3. çokluk kişi: $+z X /+X$. Tuvacada ilgi durum eki ise $+n X \eta /+d X \eta /+t X \eta$ şeklindedir (İshakov ve Palmbah 2019: 119-120). İkinci durumda ise öbek yapının sadece baş ögesi ek almaktadır. Bu durumda öbeğin tümleç konumu eksiz, baş ögesi ise iyelik ekli olarak karşımıza çıkmaktadır.

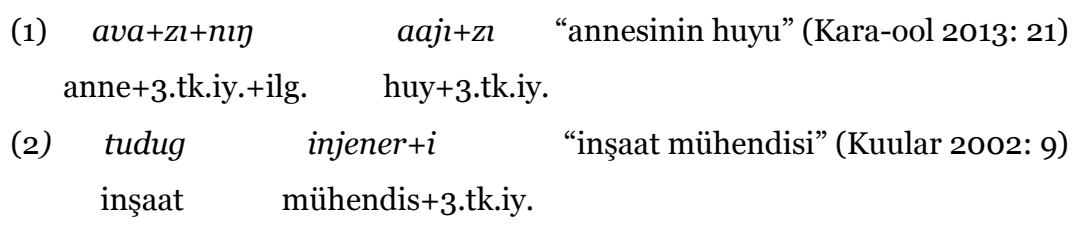

Bir AÖ'nün tümleci konumunda yer alabilen sözcüklerden ikincisi sıfatlardır. Sıfat + ad yapısındaki AÖ’lerde öbeğin her iki ögesinde de biçim bilgisel bir işaretleme yoktur.

$$
\begin{aligned}
& \text { (3) anıyak ool "genç oğlan" (Suvan 2009: 7) } \\
& \text { Genç oğlan }
\end{aligned}
$$

Belirleyiciler, geleneksel dil bilgisinde genel olarak sıfat kategorisi içerisinde ele alınmaktadırlar. Ancak bu yapılar sıfatlardan söz dizimsel ve anlam bilimsel olarak farklı özelliklere sahiptirler. $\mathrm{Bu}$ sebeple belirleyiciler, bir söz dizimi birimi olarak AÖ yapılarında ayrıca ele alınmalıdır. Abney belirleyicileri tanımlıklar, gösterimseller, sayılar ve niceleyiciler olarak alt başlıklara ayırmıştır (1987: 169-223). Bu çalışmada Türkçenin söz dizimi ve öbek yapı kuralları dikkate alınarak belirleyici $+a d$ yapısındaki AÖ’ler gösterimseller, niceleyiciler ve sayı kategorisi ile birlikte soru belirleyicileri bakımlarından ele alınmıştır.
(4) döö torlaa+lar "şu keklikler” (Dongak 2006: 5)
şu keklik+çk.
(5) çamdık kijitler "bazı kişiler" (Lodoydamba 2005: 62)
bazı kişi+çk.
(6) dört öreel “dört oda" (Monguş ve Kuular 1995: 5)
dört oda
(7) kayı odurug+lar "hangi satırlar?" (Kara-ool 2013: 40)
hangi satır+çk.




\section{2. İşlevsel dil bilgisi ve söz dizimsel işlevler}

Dil bilim çalışmalarında bir dilin yapısını ve işleyişini belirlemek adına çok sayıda farklı yaklaşımın olduğu görülmektedir. Bununla birlikte 20. yüzyılın başından itibaren iki temel görüş öne çıkmaktadır. Bu iki görüş yapısal ve işlevsel yaklaşımdır. Yapısal yaklaşımda dil, yapısal bir nesne olarak görülür ve dil bilgisi, bu yapısal nesneyi açıklanan yapıların anlamlarından ve kullanımlarından bağımsız olarak uygulanacak söz dizimi kuralları açısından karakterize etme girişimi olarak kavramsallaştırılır. İşlevsel yaklaşımda ise dil, öncelikle iletişimsel ilişkiler kurmak amacıyla kullanılan, insanlar arasındaki sosyal etkileşimin bir aracı olarak kavramsallaştııılır. Bu yaklaşımda dil, insanların sosyal etkileşiminde bir araç olarak görülür. İşlevsel dil bilgisine göre bir dil teorisi, dilsel ifadelerin oluşumunun altında yatan kuralları göstermekle yetinmemeli, aynı zamanda bu kuralların ve ifadelerin kullanılma şekillerine göre işlevlerini de açıklamaya çalışmalıdır (Dik 1997: 3). Bu anlamda İşlevsel dil bilgisi, dilin tümce, söz dizimi, söz öbekleri gibi yapısal birliklerinin işlevlerini inceleyen bir dil bilgisi dalıdır. Kuramın temelinde, dil bilgisel yapıların anlam bilimsel yönü yer almaktadır. Ancak işlevsel dil bilgisinin inceleme alanı, bağımsız yapıların veya birliklerin anlamsal işlevlerini ele almakla sınırlı değildir. Temel çıkış noktası, dil bilgisel yapı ve birliklerin birbirleriyle olan etkileşiminden doğan işlevlerdir. Anlam bilim, edim bilim açısından bir araç; söz dizimi ise anlambilim açısından bir araç olarak kabul edilir. Bu görüsse göre bağımsız bir söz diziminden söz edilemez (Dik 1997: 8).

İşlev, dilde bir dil bilgisi biriminin kullanılma amacı, söylem, metin ya da tümcede dil birimlerinin görevleri ya da gördükleri iş biçiminde tanımlanabilir. Dilin işlevleri, araştırmacılar tarafından farklı şekillerde sınıflandırılmıştır. İşlevsel dil bilgisinde dilin birincil işlevi, bildirişimi sağlamaktır. Bunun dışında araştırmacılar; dilin anlatımsallık, çağrı, gönderim gibi farklı işlevlerinden söz etmişlerdir. İşlev teriminin bir başka tanımı ise "bir tümcede bir dil biriminin diğer dil birimleriyle ilişkisi sonucu yerine getirdiği iş veya görev"dir. İşlev teriminin bu ikinci tanımı, doğrudan söz dizimsel işlevlere işaret etmektedir. Bu anlamda söz dizimsel işlevler, dil bilgisel birimlerin tümce içindeki ilişkilerine dayanan işlevler olarak kabul edilmektedirler (İmer, Kocaman ve Özsoy 2011: 161; Vardar 2002: 122).

Dik, İşlevsel dil bilgisinin üç farklı seviyede işlevsel ilişkileri yansıttığını ifade etmektedir: 1. Anlamsal İşlevler, 2. Söz Dizimsel İşlevler, 3. Pragmatik İşlevler. Söz dizimsel işlevlerin ise dil bilimsel bir ifadede yer alan birlikler arasındaki ilişkileri ifade eden işlevler olduğunu belirtmiş ve bu işlevlerin özne ve nesne olarak ifade edilebileceğini dile getirmiştir (Dik 1997: 25). Dik, burada tüm dillere uygulanabilen evrensel işlevleri belirlemek adına söz dizimsel işlevleri özne ve nesne olarak sınırlandırmıştır. Bu çalışmada Tuvacada AÖ’lerin söz dizimsel işlevleri ele alınmıştır. Bu sebeple çalışmamızda söz dizimsel işlevler özne ve nesne ile sınırlı tutulmamıştır. Özne ve nesne gibi kavramlar dil bilgisel kategorilerin aksine dil bilgisel işlevleri ifade ederler. Bir başka deyişle bu kavramlar, yukarıda da değinildiği gibi tümcenin yapısal birimleri arasındaki ilişkilerden doğan işlevleri yansıtır. Aynı şekilde öbek yapılar da bir dil bilimsel ifadede yer alan yapısal birlikler olarak tümcede diğer birimler ile belirli anlamsal ilişkiler içinde bulunmaktadırlar. Örneğin, basit bir şekilde, bir AÖ, tümcede özne işlevinde yer alabilmektedir (Chomsky 1965: 68-71).

Görüldüğü gibi işlevsel dil bilgisi bağlamında, öbek yapılar arasındaki ilişkiler de söz dizimsel işlevleri karşılayabilmektedir. Öbek yapılar, söz diziminin en önemli parçasıdır. Bu sebeple söz dizimini anlamak için öbek yapı kurallarını anlamak gerekir. Öbek yapı kuralları, bir tümcenin anlaşılabilmesi için ayrıştırma yöntemini kullanır. Öbekler, tümce içinde çeşitli söz dizimsel işlevler üstlenen en az bir ya da daha fazla sözcükten oluşan yapılardır. Bir öbek yapıda bulunan baş ve tümleç ögeleri, öbeğin iç 
yapısının söz dizimsel işlevlerini yansıtan ögelerdir. Bununla birlikte öbeğin tümcenin diğer ögeleriyle olan ilişkisine göre üstlendiği birtakım söz dizimsel işlevleri söz konusudur.

Öbek yapılar ,temelde baş ögenin sözcük türüne göre adlandırılmıştır. Bu tasnif, sözlüksel kategorilere dayanmaktadır. İşlevsel dil bilgisinde, bu kategorik kavramların yerini ögeler arasındaki ilişkiler almıştır. Örneğin Chomsky, tümceyi bir AÖ ve EÖ olarak sözlüksel kategorilerle ele alırken; İşlevsel dil bilgisinde tümce, özne ve yüklem biçiminde söz dizimsel işlevlerle açlklanmaktadır (Altundaş [baskıda]). Söz dizimsel işlevler, temelde öbeklerin eylemle olan ilişkisini yansıtır. İşlevsel dil bilgisine göre sözlüksel kategorilere göre adlandırılan bir AÖ, tümcede ögeler arasındaki ilişkiyi yansıtmaz. Bununla birlikte özne gibi bir kavram, tümcede yer alan diğer ögelerden bağımsız olarak tek başına anlamlı bir şey ifade etmez. Bunun sebebi, özne kavramının tümcenin diğer ögeleriyle olan ilişkisini yansıtmasıdır. İşlevsel dil bilgisi, tümcede yer alan öbek yapıları diğer ögelerle olan ilişkisi açısından ele almaktadır. İşlevsel dil bilgisi, tümcede bir öbek yapının ne tür bir öbek olduğunu bildirmekle beraber bu öbeğin tümcede yer alan diğer ögelerle ilişkisi bağlamında hangi işlevleri üstlendiği üzerinde de durmaktadır (Dik 1997: 25). Tümcede işlevsel açıdan bir öbek yapı; özne, nesne, dolaylı tümleç, zarf tümleci ve yüklem konumlarında bulunabilir.

\section{Tuvacada Aö’lerin söz dizimsel işlevleri}

Tümcenin özne, nesne, dolaylı tümleç, zarf tümleci ve yüklem olmak üzere beş temel ögesi bulunmaktadır. Evrensel dil bilgisine göre tüm ögeler, eylemin yönetimindedir. Tümcenin ögeleri, çeşitli işlevler üstlenerek tümcenin kurucu üyeleri konumunda farklı biçimlerde oluşabilmektedirler. $\mathrm{Bu}$ anlamda tümcede bir ögeye tek bir sözcük karşıllk gelebileceği gibi birden fazla sözcükten oluşan öbek yapılar da karşlık gelebilmektedir. Bir öbeğin tümcede bir ögeye karşılık gelmesi, bir başka deyişle bir öbek yapının özne, nesne vb. biçiminde adlandırılması, bir anlamda öbeğin söz dizimsel işlevini ifade etmektedir. Yukarıda da belirtildiği gibi İşlevsel dil bilgisinde söz dizimsel işlevler, ögeler arasındaki ilişkiye dayanır. Dolayısıyla söz dizimsel işlevleri yansıtan tümcenin ögeleri de ögeler arasındaki ilişkiden doğmaktadır. Bu anlamda AÖ’lerin tümce içinde en temel söz dizimsel işlevleri, özne ve nesne ögeleridir. Bununla birlikte belirli biçim bilgisel durumlarda bir AÖ’nün tümcede özne ve nesne konumları dışında dolaylı tümleç, zarf tümleci ve yüklem söz dizimsel işlevlerini karşıladığı da görülmektedir. Söz konusu belirli biçim bilgisel yapılar da İşlevsel dil bilgisinde ögeler arasındaki ilişkiden doğan ve ögeleri birbirine bağlayan unsurlar olarak karşımıza çıkmaktadır. Tümce ögelerinin işlevleri, durum ekleri tarafından belirlenmektedir. Tümce içinde bir öbek yapıdan oluşan tümcenin ögeleri tek birimli ögeler gibi işlem görmektedir. Bilindiği gibi öbek yapılar, kendi içerisinde yönetim çerçevesi kapsamında birtakım bă̆ımlılıklara ve işlevlere sahiptir. Temel tümce ile bir ögeye karşıllk gelen öbek yapı arasındaki biçim bilgisel bağlantı ise öbeğin yönetici ögesi ile kurulmaktadır (Erkman Akerson ve Özil 2015: 55).

\section{1. Özne işlevinde Aö’ler}

Evrensel dil bilgisine göre tümce, bir AÖ ve EÖ'den oluşmaktadır. İşlevsel dil bilgisi ise tümceyi temelde özne ve yüklem biçiminde söz dizimsel işlevlerine göre analiz etmektedir. Bu anlamda her iki görüşün ortak noktası tümcede özne görevinde bir AÖ'nün yer almasıdır. Yani, evrensel olarak özne işlevi, bir AÖ ile karşlanmak zorundadır. Ancak tümcenin zorunlu iki temel ögesinden biri olan öznenin biçim bilgisel açıdan bir durum eki alma zorunluluğu yoktur. Bir başka deyişle özne konumundaki AÖ’nün yalın durumda olması gerekmektedir. Üstünova, Yalın Durum Karmaşası adlı çalışmasında biçimsel olarak ek almamış bütün ad soylu sözcüklerin yalın durum olarak ele

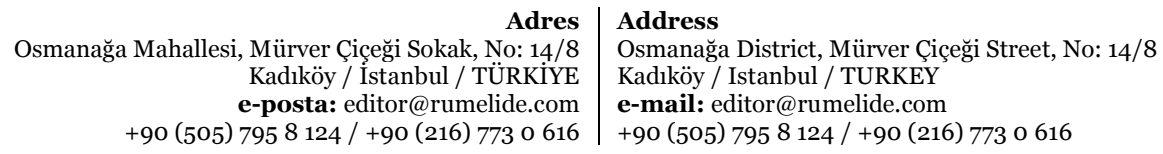


alınmaması gerektiğini ifade eder. Bu anlamda, sözde özne ve belirtisiz nesne durumundaki ad ve AÖ’lerin yalın durumda olamayacağını savunur (2007). Ancak bu çalışmada yalın durum terimi, biçim bilgisi esas alınarak kullanılmıştır. Yani, biçim bilgisel olarak herhangi bir durum eki almayan ad veya AÖ’ler yalın durum terimi ile ifade edilmiştir. Bunun amacı, özne görevini üstlenen AÖ’nün tümcenin diğer ögeleriyle ilişkisinin biçim bilgisel değil, anlam bilimsel olduğunu göstermektir.

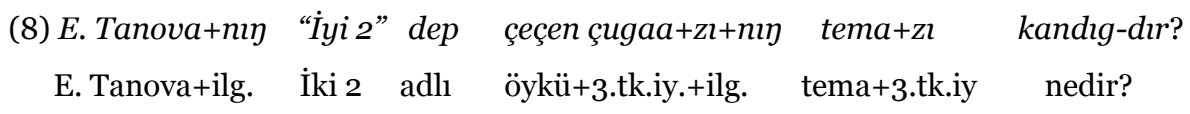

“E. Tanova’nın ‘'̇ki 2’ adlı öyküsünün teması nedir?” (Kara-ool 2013: 29)

Yukarıdaki tümcede söz dizimsel işlevler açısından E. Tanovanı "İyi 2" dep çeçen çugaazını temazı “E. Tanova’nın ‘İki 2’ adlı öyküsünün teması” AÖ’sü özne görevindedir. Görüldüğü gibi söz konusu AÖ ile yüklem arasında biçim bilgisel bir bağlantı yani herhangi bir durum eki bulunmamaktadır. AÖ'nün tümcede özne görevinde olduğu tamamen anlam bilimsel olarak tespit edilebilmektedir.

Bir tümcede, temelde iki tür öge bulunmaktadır: temel öge ve seçimlik öge. Temel ögeler, bir tümcenin dil bilgisi açısından doğru kabul edilebilmesi için gereken zorunlu ögelerdir. Seçimlik ögeler ise anlamsal açıdan tümceleri zenginleştiren, çıkarıldığında tümcelerin dil bilgiselliğini koruduğu ögelerdir (Erkman Akerson ve Özil 2015: 57). Özne, Evrensel dil bilgisinde zorunlu öge olarak ele alınmaktadır.

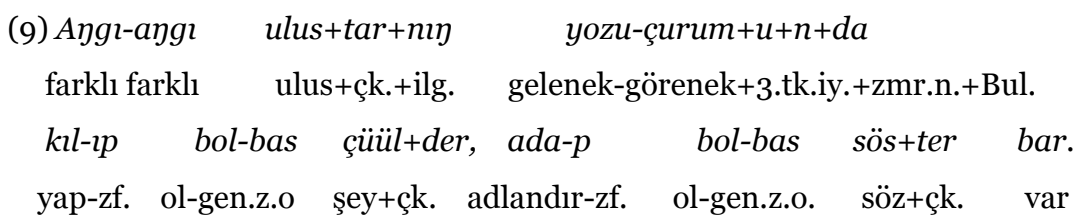

"Farklı farklı ulusların gelenek ve göreneklerinde yapılması yasak şeyler ve söylenmesi yasak sözler vardır." (Monguş ve Kuular 1995: 30)

Yukarıdaki tümcede özne işlevini kılp bolbas çüülder, adap bolbas söster "yapılması yasak şeyler ve söylenmesi yasak sözler” AÖ’sü karşllamaktadır. Söz konusu AÖ, özne görevi dolayısıyla tümcede zorunlu bir ögedir. Özne konumundaki AÖ’nün tümceden çıarılması durumunda, tümcenin dil bilgiselliği bozulur. Burada Türkçede öznesiz tümce olarak adlandırılan tümce yapılarından da söz etmek gerekir. Bu tür tümcelerde özne işlevinin söz dizimsel dizilişte yer almadığı görülmektedir. Ancak hiçbir eylemin edici (agent) olmadan gerçekleşmesi düşünülemez. Bu anlamda Chomsky'nin derin yapı kavramından hareketle öznesiz tümce yapılarının da derin yapıda birer özne alma zorunlulukları bulunmaktadır.

Tümceyi kuran eylemin etken veya edilgen olması, işlevsel açıdan tümce ögelerinin de işlevini etkilemektedir. Bu anlamda etken tümcede nesne işlevinde yer alan öge, edilgen tümcede özne söz dizimsel işlevini yerine getirmektedir. Söz konusu durum, özne işlevinin tümcede zorunlu bir öge ile karşılanma gerekliliğini göstermektedir. Edilgen bir tümcede özne görevindeki AÖ’nün diğer ögelerle ilişkisi karışık bir durumdur. Bu ilişkinin biçim bilgisel olarak işaretlenmediği açıktır. Özne işlevinin anlam bilimsel olarak belirlenmesi, geleneksel dil bilgisinde "sözde özne" olarak adlandırılan yapıların özne veya nesne olarak ele alınmasını belirsiz kılmaktadır. Türkçede öznenin belirlenmesi konusunda genel olarak dil bilgisel, edim bilimsel veya anlam bilimsel yaklaşımlar benimsenmektedir. $\mathrm{Bu}$ yaklaşımların aynı anda kullanılması, tümcenin ögelerini belirlemede karışıklık yaratmaktadır. Ancak bu durum ayrı bir çalışmanın konusudur (Öznenin belirlenmesi ve edilgen tümcede öznenin durumu

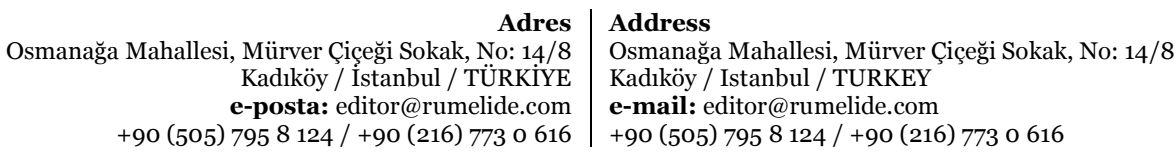


hakkında detaylı bilgi için bk. Doğan 2015 ve Üstünova 2006). Bu çalışmada yalnızca Tuvacada AÖ’lerin hangi söz dizimsel işlevleri hangi biçim bilgisel durumlarda karşlayabildiği ele alınmaktadır. Bu sebeple burada edilgen tümcenin öznesi konumundaki AÖ ile tümcenin diğer ögeleri arasındaki ilişkinin biçim bilgisel olarak işaretlenmediğini söylemekle yetinilecektir.

$$
\begin{array}{clrrrr}
\text { (10) ... ög-büle+niy taybıy } & \text { amıdıral+ı } & \text { baza } & \text { katap } & \text { üzül-gen. } \\
\text { aile+ilg. } & \text { barış hayat+3.tk.iy. } & \text { bağ. } & \text { yine } & \text { sonlan-g.z.2 }
\end{array}
$$

"Ailenin barış hayatı da yine sonlandı." (Kuular 2002: 36)

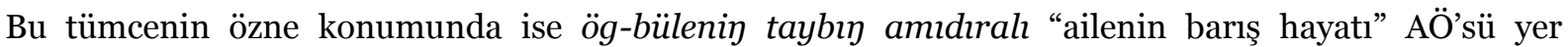
almaktadır. Görüldüğü gibi edilgen tümcenin öznesi konumunda yer alan AÖ ile diğer ögeler arasında biçim bilgisel bir bağlantı bulunmamaktadır. Ayrıca yine bir AÖ ile karşılanan özne konumundaki öge, tümcenin zorunlu ögesi durumundadır.

\subsection{Nesne işlevinde Aö’ler}

Nesne söz dizimsel işlevi, doğrudan eylemle ilişkili bir görevi tanımlamaktadır. Bir başka deyişle nesne kavramı, eylemlerin yankategorileme çerçevesi ile ilgilidir. Bir eylemin nesne alma durumu, yankategorileme çerçevesine göre belirlenmektedir. Bu durumda eylemler, geçişli ve geçişsiz olmak üzere ikiye ayrılmaktadır. Yankategorileme çerçevesine göre nesne alabilen eylemler ile kurulan tümcede nesne konumu, Evrensel dil bilgisinde zorunlu bir öge olarak kabul edilmektedir.

Türkçede ögeler arasındaki bağlantı durum ekleriyle sağlanmaktadır. Geleneksel dil bilgisine göre tümcede bir ögenin nesne olarak kabul edilebilmesi için yalın veya belirtme durum ekli olması gerekmektedir. Burada yukarıda da belirtildiği gibi yalın durum, belirtisiz nesne konumundaki ad ve AÖ’lerin herhangi bir durum ekiyle işaretlenmediğini ifade etmek için kullanılmıştır. Bu noktada tümcenin ögelerinin belirlenmesinde durum ekleri, bir ölçüt olarak görülmektedir. İşlevsel dil bilgisine göre tümcenin ögeleri, anlamsal rollere yani işleve göre belirlenmektedir. Durum ekleri ile anlamsal roller arasında doğrudan bir ilişki söz konusudur. Ancak bir durum eki, farklı anlamsal rollere işaret edebileceği gibi bir anlamsal rol de farklı durum ekleri tarafından karşlanabilmektedir (Doğan 2010: 227-229). Bu anlamda Sarıca, ayrılma ve yönelme durum ekli ögelerin de nesne işlevinde kullanılabileceğini ifade etmiştir (2015: 53-54). Belirtme durum eki dışında yönelme ve ayrılma durum ekli ögelerin de nesne olarak kabul edilmesi eylemlerin istemi ile ilgilidir. Yani eylemlerin belirtme, yönelme veya ayrılma ekli olarak gerektirdiği tamlayıcılar, nesne olarak kabul edilmektedir. Nesnenin belirlenmesi ile ilgili yaklaşımlardan biri de eylemin istemidir. Buna göre bir eylem aynı anda yalın, belirtme, yönelme ve ayrılma durum ekli tamlayıcıları isteyebilir. Bunlar içerisinde belirtme ve yönelme durum ekli olmak üzere en az iki tamlayıcı gerektiren eylemler geçişli olarak kabul edilmiş ve bu eylemlerin gerektirdiği ögeler de nesne olarak ele alınmıştır (Doğan 2010: 229). Nesne konumunda yer alan bir AÖ'nün baş ögesi ile yüklem ögesi arasındaki gramatikal ilişki, yalın, belirtme ve yönelme durum ekleriyle sağlanabilmektedir. Tuvacada belirtme durumu $+t X,+d X,+n X$ ve $+n$ ekleriyle sağlanmaktadır (Sat ve Salzınma 1980: 114). Yönelme durumu ise $+G A$ eki ile yapılmaktadır (İshakov ve Palmbah 2019: 133).

$$
\begin{aligned}
& \text { (11) ... olar+ga yanzı-bürü ajll+dar keldrr-gan. } \\
& \text { onlar+yön. çeşitli iş+çk. yaptır-g.z.2 } \\
& \text { “... onlara çeşitli işler yaptırdı.” (Monguş ve Kuular 1995: 66) }
\end{aligned}
$$


Yukarıdaki tümcede yüklem konumunda kıldır- "yaptırmak" geçişli eylemi bulunmaktadır. Bu sebeple tümcede nesne konumu bulunmalıdır. Nesne konumunda ise sıfat $+a d$ yapısındaki yanzı-bürü ajıldar “çeşitli işler” AÖ’sü yer almaktadır. Söz konusu AÖ’nün tümcede nesne işlevini yerine getirdiği anlam bilimsel olarak tespit edilebilmektedir. Görüldüğü gibi AÖ ile yüklem arasında biçim bilgisel olarak bir bağlantı söz konusu değildir. İki öge arasındaki ilişki, eylemin yönetim çerçevesi bir başka deyişle yankategorileme çerçevesiyle bilinmektedir.
(12) Avtorlug tool+du ayannig nomçu-yar.
yazarlık öykü+bel. güzel oku-2.çk.k.
"Yazarlık öyküsünü güzelce okuyunuz." (Kara-ool 2013: 72)

Bu tümcede yüklem görevinde geçişli bir eylem olan nomçu- "oku-" eylemi yer almaktadır. Yüklemi geçişli bir eylem olan tümcede nesne bulunmak zorundadır. Bu tümcede ise eylemin yankategorileme çerçevesi gereği nesne işlevini, sıfat + ad yapısındaki avtorlug tool "yazarlık öyküsü” AÖ'sü karşlamaktadır. Tümcede söz konusu AÖ ile yüklem arasındaki gramatikal ilişki ise $+d u$ belirtme durum ekiyle sağlanmıştır.

$$
\begin{aligned}
& \text { (13) Taakpl }+z \imath+n \text { çoldak söösken } \\
& \text { sigara+3.tk.iy.+bel. kısa çayır melikesi (keçisakalı bitkisi) } \\
& \text { dayza+zl }+n+g a \quad \text { dig-e ber-gen } \\
& \text { pipo+3.tk.iy.+zmr.n.+yön. } \quad \text { yerleştir-zf.+arte.+g.z.2 }
\end{aligned}
$$

"Sigarasını çayır melikesi piposuna yerleştiriverdi.” (TS 1: 441)

Bu tümcede ise yüklem konumunda yer alan dige ber- "yerleştiriver-" eyleminin belirtme ve yönelme durum ekli olmak üzere en az iki tamlayıcı gerektirdiği görülmektedir. Bu sebeple tümcede nesne konumunda iki öge vardır. İlk olarak, gramatikal ilişkinin $+n$ belirtme eki ile sağlandığı taakpızın "sigarasını" sözcügünün nesne işlevinde olduğu görülmektedir. Diğer nesne konumundaki öge ise sıfat + sıfat + ad yapısındaki çoldak söösken dayza "küçük çayır melikesi pipo” AÖ’südür. Nesne işlevindeki ikinci öge ile yüklem arasındaki gramatikal ilişki ise $+g a$ yönelme durum ekiyle sağlanmıştır.

\subsection{Dolaylı tümleç işlevinde Aö’ler}

Söz dizimsel işlevler bağlamında tümleç terimi; nesne, dolaylı tümleç, zarf tümleci ve edat tümleci terimlerini kapsayacak şekilde eylemin anlamını çeşitli açılardan tamamlayan ve belirginleştiren söz veya söz öbekleri biçiminde ele alınmıştır. Dolaylı tümleç kaynaklarda yüklemin anlamını bütünleyen ve tümcede yönelme, bulunma ve ayrılma durum ekleriyle yer alan öge olarak ele alınmaktadır. Alanyazında tümcenin ögeleri, temelde iki şekilde belirlenmektedir. Bunlardan ilki biçimci yaklaşım, ikincisi ise anlam bilimsel yaklaşımdır. Ancak Türkçe dil bilgisi çalışmalarında her iki yöntemin birbiriyle eş zamanlı kullanıldığı görülmektedir. Bu durum ise kullanımda bir tutarsızlı̆̆ beraberinde getirir. (Dolaylı tümleç ögesinin ele alınışı üzerine detaylı bilgi için bk. Kerimoğlu 2019). Bu çalışmada ise işlevsel dil bilgisi esas alınmıştır. Dolayısıyla tümcede dolaylı tümleç ögesi anlamsal olarak işlev yönüyle belirlenmiştir. Tümcenin ögelerinin anlam bilimsel ölçütlerle ele alınması noktasında da araştırmacılar arasında bir birlik olduğu söylenemez. Bu sebeple çalışmamızda dolaylı tümleç ögesi yer bildirme işleviyle ele alınmıştır. Söz konusu yer bildirme işlevi, tümcede eylemin yankategorileme çerçevesi dışında yer alabilir. Yani, tümcede dolaylı tümleç işlevini taşıyan bir öge, seçimlik öge durumunda yer alabilmektedir. Tuvacada dolaylı tümleç işlevindeki AÖ’lerin yüklemle olan gramatikal

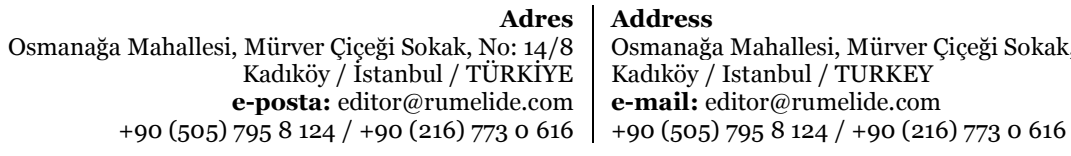


ilişkisi ise yönelme, yön-gösterme, bulunma ve ayrılma durum ekleriyle sağlanmaktadır. Tuvacada yönelme durumu $+G A$, yön-gösterme durumu $+c ̧ e /+j e$ ve $+D X v A$, bulunma durumu $+D A$, ayrılma durumu ise $+D A n$ ekiyle sağlanmaktadır (İshakov ve Palmbah 2019: 133-144). Aşağıdaki tümcelerde dolaylı tümleç işlevinde yer alan AÖ’lerin yüklem ile arasındaki gramatikal ilişkisi farklı durum ekleri bakımından örneklendirilmiştir:

$\begin{array}{lllllll}\text { (14) Saylkmaa Salçakovna } & 1960 & c ̧ l l+d \imath \eta & \text { dekabr' } & 12-d e & \text { Bay Tayga } \\ \text { Sayllkmaa Salçakovna } & 1960 & \text { yll+ilg. } & \text { Aralık } & 12+\text { bul. } & \text { Bay Tayga } \\ \text { kojuun+u+nuy } & \text { Bay-Tal } & \text { suur+u+n+ga } & \text { törüttün-gen. } \\ \text { bölge+3.tk.iy.+ilg. } & \text { Bay-Tal } & \text { köy+3.tk.iy.+zmr.n.+yön. } & \text { doğ-g.z.2 }\end{array}$

"Saylıkmaa Salçakovna 1960 yllının 12 haziranında Bay-Tayga bölgesinin Bay-Tal köyünde doğmuştur." (Kara-ool 2013: 152)
(15) Mar’ya İvanouna
ool+dar+nıy
oğlan+çk.+ilg.
Mar'ya İvanovna
$k a y \imath+z n+n+c ̧ e-d a a$
topta-p kör-gen.
hangi+3.tk.iy.+zmr.n.+yöng.+bağ. dikkatle bak-zf.+arte.-g.z.2
"Mar'ya İvanovna oğlanların birisine dikkatle baktı." (Kara-ool 2013: 19)

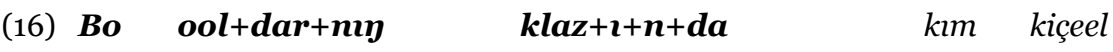
$\mathrm{Bu} \quad$ oğlan+çk.+ilg. $\quad$ sinıf(klass)+3.tk.iy.+zmr.n.+bul. kim ders
bürü+zü+n+ge beletken-ip, eki öören-ip tur-ar-drr?
tam+3.tk.iy.+zmr.n.+yön. hazırlan-zf. iyi öğren-zf.+arte.+gen.z.+bild.

"Bu oğlanların sınıfinda kim tüm derslere hazırlanıp iyi öğrenmiştir?” (Kara-ool 2013: 29)

(17) Çedi-ses hon-ganda, Sodunam-Balçır Daa kojuun+dan ee-p kel-gen.

Yedi-sekiz konakla-zf. Sodunam-Balçır Daa bölge+ayr. dön-zf.+arte.-g.z.2

"Sodunam-Balçır, yedi sekiz gece konakladıktan sonra Daa bölgesinden dönüp geldi.” (Suvan 2009: 136)

\subsection{Zarf tümleci işlevinde Aö’ler}

Zarflar, niteleyicilerin, eylemlerin ve diğer zarfların anlamlarını pekiştiren veya kısıtlayan sözcüklerdir. $\mathrm{Bu}$ anlamda zarflar ve zarf işlevindeki sözcük veya söz öbekleri tümcede seçimlik ögeler arasında yer almaktadırlar. Zarflar, işlev bakımından tümce, eylem öbeği ve niteleme zarfları olmak üzere üçe ayrılır. İşlevsel dil bilgisinin ilgi alanına giren ögeler arası ilişkiler açısından zarflar, tümcenin ögelerinden bir tanesini oluşturur. Bununla birlikte zarflar, bir EÖ’nün tümleci konumunda yer alan ögesidir. Söz konusu sinıflandırma, zarfların tümcede söz dizimsel konumu itibariyle yapılmıştır. Ayrıca zarfların tümcede çeşitli işlevleri vardır. Bu anlamda alanyazında zarflar; zaman zarfları, yeryön zarfları, durum zarfları, sebep-sonuç zarfları ve miktar zarfları başlıkları altında değerlendirilmektedir (İmer, Kocaman ve Özsoy 2011: 47). Söz konusu değerlendirme, işlevsel dil bilgisi yaklaşımını yansıtmakta yani anlamsal rolleri ön plana çıkarmaktadır. Söz dizimsel işlevler bağlamında bu işlevleri yansıtan tüm ögeler, tümcenin ögeleri açısından zarf tümleci olarak kabul edilebilir. Ayrıca her işlev için ayrı birer söz dizimsel işlev de tayin edilebilir. Ancak söz konusu durum bu çalışmanın konusu değildir. Bu çalışmada AÖ’lerin tümcede hangi söz dizimsel işlevlerde yer alabileceği ele alınmaktadır. Bu sebeple burada söz dizimsel işlevlerin ve tümcenin ögeleri konusunun farklı bakış açılarıyla yeniden değerlendirilmesinde fayda olduğunu söylemekle yetineceğiz. Bununla birlikte işlevsel dil bilgisi temelinde hangi durum ekiyle işaretlenmiş olursa olsun yer bildiren tüm

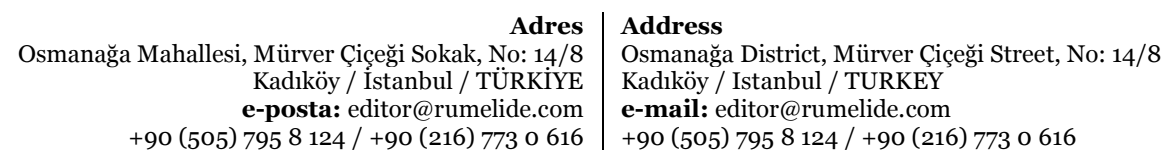


ögeler, çalışmamızda söz dizimsel işlev açısından dolaylı tümleç olarak değerlendirilmiştir. Bu anlamda yer-yön bildiren zarflar dışında zaman, durum, sebep-sonuç ve miktar bildiren zarflar, zarf tümleci söz dizimsel işlevi kapsamında ele alınmıştır. Yukarıda da belirtildiği gibi bu çalışmada tümcede AÖ yapısında görülüp zarf işlevinde kullanılan ögeler incelenmiştir. Bu sebeple aynı işlevleri yerine getirebilen İÖ yapıları, zarf tümleci söz dizimsel işlevi adı altında değerlendirilse de burada gösterilmemiştir.

Zarf tümleci söz dizimsel işlevini yerine getiren öge ile yüklem arasında temelde biçim bilgisel bir bağ yoktur. Ancak bilindiği gibi bir işlev farklı sentaktik biçimlerde yani farklı durum ekleriyle görülebilmektedir. $\mathrm{Bu}$ anlamda Tuvacada zarf tümleci işlevinde bir AÖ ile yüklem arasındaki gramatikal ilişki; yalın, bulunma ve ayrılma durum ekleriyle sağlanabilmektedir. Aşağıdaki tümcelerde yükleme farklı durum ekleriyle bağlanan zarf tümleci işlevindeki AÖ’ler örneklendirilmiştir:

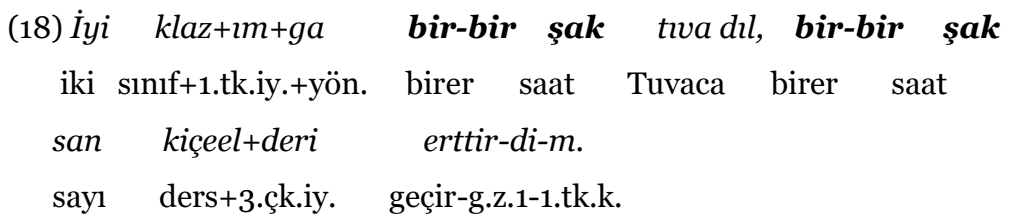

"İki sınıfımda birer saat Tuvaca ve birer saat matematik derslerini işledim” (TS 2: 636)

\begin{tabular}{|c|c|c|c|c|}
\hline 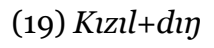 & surguul+darı, & anıyak+tarı & diştan-er & hün+ner+de \\
\hline Kızıl+ilg. & öğrenci+3.çk.iy. & genç+3.çk.iy. & dinlen-ade. & gün+çk.+bul. \\
\hline ol dag+nig & $k u r+\imath+n+c ̧ e$ & $\ddot{u} n-i$ & agaarla-ar. & \\
\hline
\end{tabular}

“Kızll'ın öğrencileri, gençleri tatil günlerinde o dağa çıkıp gezerler.” (Monguş ve Kuular 1995: 40)

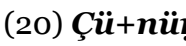
ujur+u+n+dan
bo kurgan pensiya

$\mathrm{Ne}+$ ilg. $\quad$ sebep+3.tk.iy.+zmr.n.+ayr. bu yaşlı emekli maaşı

al-bayn bar-gan ço-or?

al-zf.+arte-g.z.2+arte.(çor-)+gen.z.

“Ne sebeple bu yaşlı, emekli maaşı almamış?” (TS 2: 553)

\subsection{Yüklem işlevinde Aö’ler}

Evrensel dil bilgisine göre tümce, özne AÖ'sü ile yüklem EÖ’sünden oluşmaktadır. Genel olarak tümleç terimiyle ifade edilen nesne, dolaylı tümleç ve zarf tümleci ögeleri ise tümceyi yer, zaman vb. anlamsal yönlerden tamamlayan, yüklemle ilişkili unsurlardır. Bu açıdan bakıldığında yüklem tümcenin temel ögesidir. Özne dâhil tüm ögeler doğrudan veya dolaylı olarak yüklemle ilişkilidir. Öznenin yüklemle ilişkisi, anlam bilimsel olarak görülmektedir. Bu anlamda yüklem tümcenin kurucu ögesidir. Tümcenin kurucu ögesi konumunda yer alan eylem, bu özelliğini yönetme kapasitesinden alır. Yönetim çerçevesine sahip olan eylem, tümcenin diğer ögelerini anlamsal ve biçim bilgisel yönlerden etkiler. Bu sebeple yüklem ile tümcenin diğer ögeleri arasında biçim bilgisel veya anlamsal bir bağ söz konusudur. Yüklem, tümcede temelde iki biçimde görülür: Birincisi eylem veya EÖ'den oluşan yüklemler; ikincisi ise ad veya AÖ'den oluşan yüklemler. Çalışmanın konusu gereği, burada AÖ durumundaki yüklem söz dizimsel işlevi değerlendirilmiştir. Bir AÖ’nün yüklem olabilmesi için bildirme çekimine girmesi gerekir. Bildirme kategorisi Türkçe dil bilgisi çalışmalarında genel olarak "ek-eylem" adı altında incelenmiştir. Tuvacada diğer Türk lehçelerinde olduğu gibi ek-eylemin genişşimdiki zaman, geçmiş zaman ve şart çekimi mevcuttur. Ancak bir AÖ, sadece ek-eylemin geniş-

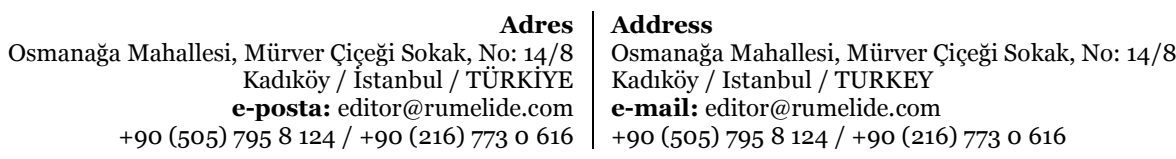


şimdiki zaman ve geçmiş zaman çekimlerinde yüklem konumunda yer alabilmektedir. Tuvacada ekeylemin geniş-şimdiki zaman çekimi isim + kişi zamiri biçiminde olmaktadır. Ayrıca $+D X r$ bildirme ekinin de kullanıldığı görülmektedir. Tuvacada ek-eylemin geçmiş zaman çekimi diğer Türk lehçelerinden farklı olarak bol-, tur- ve çor- gibi yardımcı eylemlere geçmiş zaman eklerinin getirilmesiyle yapılmaktadır (Tosun 2011: 257-266). Ayrıca Tuva Türkçesinde geniş-şimdiki zaman bildirmesinde Eski Türkçe döneminden itibaren tanıklanan ol enklitiği ile birlikte çüve sözcüklerinin de kullanıldığı görülmektedir. (Tuvacada bildirme kategorisi hakkında detaylı bilgi için bk. Altundaş 2020). Aşağıdaki tümcelerde sırasıyla ek-eylemin geniş-şimdiki zaman ve geçmiş zaman çekimlerinde yüklem işlevinde yer alan AÖ’ler örneklendirilmiştir:

\author{
(21) Şınap, kaş klass+ta sen? \\ gerçekten kaç sınıf+bul.+bild. \\ “Gerçekten, (sen) kaçıncı sınıftasın?” (Monguş ve Kuular 1995: 143) \\ (22) Inda Tiva+lar+niy san+l 4 muy ajig kiji bol-gan. \\ orada Tuva+çk.+ilg. sayı+3.tk.iy. dört bin fazla kişi arte.-g.z.2 \\ “Orada Tuvaların nüfusu dört binden fazlaydı.” (Monguş ve Kuular 1995: 160)
}

\title{
Sonuç
}

Bu çalışmada, Tuvacada AÖ’lerin söz dizimsel işlevleri incelenmiştir. Buna göre bir AÖ’nün tümcede her türlü söz dizimsel işlevi yerine getirebildiği görülmektedir. Bir başka deyişle $a d+a d, s \imath f a t+a d$ veya belirleyici + ad yapılarında görülebilen her türlü AÖ; tümcede özne, nesne, dolaylı tümleç, zarf tümleci ve yüklem görevinde yer alabilmektedir.

Bir AÖ’nün tümcede temel söz dizimsel işlevleri, özne ve nesne konumlarıdır. Özne görevinde bir AÖ, Türkiye Türkçesinde olduğu gibi Tuvacada da yükleme anlam bilimsel olarak bağlıdır. Yani, özne ile yüklem arasındaki ilişkiyi işaretleyen herhangi bir durum söz konusu değildir.

Nesne işlevindeki AÖ’lerin yüklemle ilişkisi, eylemin yankategorileme çerçevesinde yer aldıkları için çok belirgindir. Bu sebeple eylemler temelde nesne alabilme durumlarına göre geçişli ve geçişsiz eylemler olmak üzere ikiye ayrılır. Türkçede nesnenin belirlenmesi konusunda çeşitli yaklaşımlar bulunmaktadır. Bu çalışmada eylemin istemi doğrultusunda en az iki tamlayıcıyı gerektiren eylemler geçişli olarak kabul edilmiş ve bu eylemlerin gerektirdiği ögeler de nesne olarak ele alınmıştır. Bu anlamda Tuvacada nesne konumundaki AÖ’lerin yüklemle ilişkisinin yalın durum, belirtme durumu $(+t X,+d X,+n X$ ve $+n)$ ve yönelme durumu $(+G A)$ ile sağlandığı görülmüsstür.

Alanyazında tümcenin ögeleri, temelde iki şekilde belirlenmektedir. Bunlardan ilki biçimci yaklaşım, ikincisi ise anlam bilimsel yaklaşımdır. Bu sebeple işlevsel dil bilgisi temelli çalışmamızda dolaylı tümleç söz dizimsel işlevi, anlamsal olarak yer bildirme işleviyle değerlendirilmiştir. Bu bağlamda Tuvacada dolaylı tümleç görevindeki AÖ’lerin yüklemle ilişkisinin yönelme durumu $(+G A)$, yöngösterme durumu $(+c ̧ e /+j e$ ve $+D X v A)$, bulunma durumu $(+D A)$ ve ayrılma durumu $(+D A n)$ ile kurulduğu tespit edilmiştir.

Alanyazında zarflar; zaman zarfları, yer-yön zarfları, durum zarfları, sebep-sonuç zarfları ve miktar zarfları başlıkları altında değerlendirilmektedir. Zarfların farklı anlamsal yönlerini ifade eden bu sınıflandırma bir anlamda söz dizimsel işlevler kapsamında ele alınabilir. Bu çalışmada İşlevsel dil bilgisinden hareketle yer bildiren ögeler dolaylı tümleç olarak değerlendirilmiştir. Bu sebeple zarf

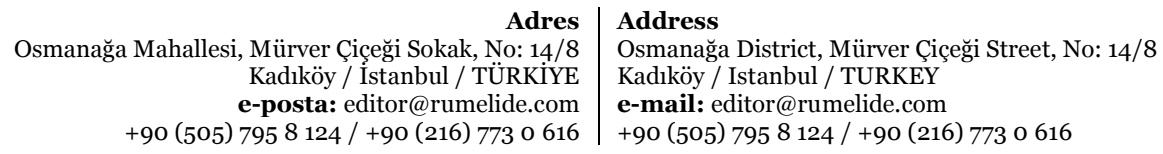


tümleci söz dizimsel işlevi, yer-yön bildiren zarflar dışında zaman, durum, sebep-sonuç ve miktar bildiren zarflar kapsamında incelenmiştir. Bu bağlamda Tuvacada zarf tümleci işlevindeki AÖ’ler ile yüklem arasındaki ilişkinin yalın, bulunma $(+D A)$ ve ayrılma durumu $(+D A n)$ ile sağlandığı görülmüştür.

Son olarak, Tuvaca'da Türkiye Türkçesinde olduğu gibi AÖ’lerin yüklem söz dizimsel işlevini yerine getirdikleri görülmektedir. Bir AÖ’nün tümcede yüklem olabilmesi için bildirme çekimine girmesi gerekir. Tuvacada diğer Türk lehçelerinde olduğu gibi ek-eylemin geniş-şimdiki zaman, geçmiş zaman ve şart çekimi mevcuttur. Ancak bir AÖ, sadece ek-eylemin geniş-şimdiki zaman ve geçmiş zaman çekimlerinde yüklem konumunda yer alabilmektedir. Tuvacada ek-eylemin geniş-şimdiki zaman çekimi temelde $a d+$ kişi zamiri biçiminde olmaktadır. Ayrıca $-D X r$ eki ile ol ve çüve enkliktleri de ekeylemin geniş-şimdiki zaman çekiminde kullanılmaktadır. Ek-eylemin geçmiş zaman çekimi ise diğer Türk lehçelerinden farklı olarak bol-, tur- ve çor- gibi yardımcı eylemlere geçmiş zaman eklerinin getirilmesiyle yapılmaktadır.

\section{Dil bilgisel notasyon için kullanılan kısaltmalar}

$\begin{array}{ll}\text { ade. } & \text { Ad Eylem } \\ \text { arte. } & \text { Art Eylem } \\ \text { bağ. } & \text { Ayrllma Durumu } \\ \text { bel. } & \text { Bağlaç } \\ \text { bild. } & \text { Belirtme Durumu } \\ \text { bul. } & \text { Bildirme } \\ \text { çk. } & \text { Bulunma Durumu } \\ \text { çk.iy } & \text { Çokluk } \\ \text { çk.k. } & \text { Çokluk İyelik } \\ \text { g.z.1 } & \text { 1. Tip Geçmiş Kamis Zan } \\ \text { g.z.2 } & \text { 2. Tip Geçmiş Zaman } \\ \text { gen.z. } & \text { Geniş Zaman } \\ \text { gen.z.o. } & \text { Geniş Zamanın Olumsuzu } \\ \text { ilg. } & \text { İlgi Durumu } \\ \text { tk.iy. } & \text { Teklik İyelik } \\ \text { tk.k. } & \text { Teklik Kişi } \\ \text { yön. } & \text { Yönelme Durumu } \\ \text { yöng. } & \text { Yön-Gösterme Durumu } \\ \text { zf. } & \text { Zarf-fiil } \\ \text { zmr.n. } & \text { Zamir n'si } \\ & \end{array}$

\section{Kaynakça}

Abney, S. P. (1987), The English Noun Phrase in Its Sentential Aspect. Basılmamış Doktora Tezi. Cambridge: M.I.T.

Aktan, B. (2016). Türkiye Türkçesinin Sözdizimi. Konya: Eğitim Yayınevi.

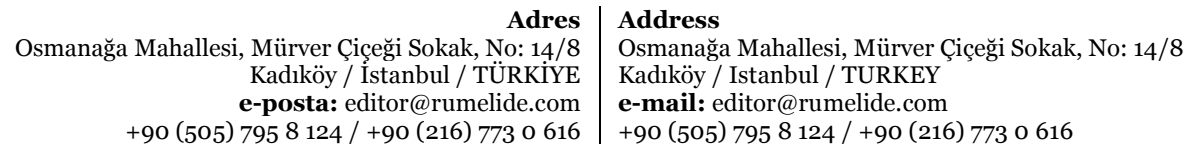


Altundaş, U. (baskıda). “Tuvacada Belirteç İşlevli Söz Öbekleri”. Hacettepe Üniversitesi Türkiyat Araştırmaları Dergisi.

Altundaş, U. (2020). “Tuva Türkçesinde Bildirme Kategorisi”. 15. Uluslararası Büyük Türk Dili Kurultayı Bildiri Kitabı. Gürcistan-Tiflis. 477-487.

Chomsky, N. (1965). Aspect of the Theory of Syntax. Cambridge: The M.I.T. Press.

Chomsky, N. (1988). Lectures on Government and Binding. Dordrecht: Foris Publications.

Chomsky, N. (2002). Syntactic Structures. Berlin/New York: Mouton de Gruyter.

Delice, H. İ. (2003). Türkçe Sözdizimi. İstanbul: Kitabevi.

Dik, S. C. (1997). The Theory of Functional Grammar. Berlin/New York: Mouton de Gruyter.

Doğan, N. (2010). "Türkçede Nesneyi Belirleme Sorunu”. Uluslararası Sosyal Arastırmalar Dergisi. 3/10 Kış, 225-230.

Doğan, N. (2015). “Türkiye Türkçesi Söz Diziminde Özne Sorunu - Dil Bilimsel Bir Yaklaşım”. Turkish Studies International Periodical for the Languages, Literature and History of Turkish or Turkic, 10/12 Yaz, 295-314.

Dongak, E. (2006). Çetkerlerge Çagaalarım. Kızıl: Tıvanın Nom Ündürer Çeri.

Erkman Akerson, F. ve Ozil, S. N. Ş. (2015). Türkçede Niteleme Slfat İşlevli Yan Tümceler. Ankara: Türk Dil Kurumu Yayınları.

Gökdayı, H. (2018). Türkçede Öbekler. İstanbul: Kriter Yayınevi.

Hirik, S. (2020). Söz Dizimi Kuramları Bağlamında Türkçede Baş Unsur. Ankara: Gazi Kitabevi.

İmer, K.; Kocaman, A. ve Özsoy, A. S. (2013). Dilbilim Sözlüğü. İstanbul: Boğaziçi Üniversitesi Yayınevi.

İshakov, F. G. ve Palmbah, A. A. (2019). Tuva Dili Grameri Ses ve Şekil Bilgisi (çev. Ekrem Arıkoğlu, Canıl Mirza Bapayeva ve Buyan Borbaanay). Ankara: Bengü Yayınları.

Kara-ool, L. S (2013). Literaturlug Nomçulga 3 Klass. Kızıl: Tıvanın Nom Ündürer Çeri.

Kerimoğlu, C. (2017). Genel Dilbilime Giriş. Ankara: Pegem Yayınları.

Kuular, N. (2002). Düüşkünnerlig Eer-dagır Oruktar. Kızıl: Tıvanı Nom Ündürer Çeri.

Lodoylamba, Ç. (2005). Arıg Suglug Tamir (çev. Kırgıs Talayeviç ve Oydan-ool Höveymey). Kızıl: Tivanın Nom Ündürer Çeri.

Monguş, D. A. ve Kuular, K. B. (1995). Tiva Dıl 6-7. Kızıl: Tıvanın Nom Ündürer Çeri.

Özsoy, S.; Balcı, A. ve Turan, Ü. D. (2012). Genel Dilbilim-I. Eskişehir: Anadolu Üniversitesi Yayını.

Sarıca, B. (2015). Türkçe Cümle Bilgisi. Ankara: Anı Yayıncılık.

Sat, Ş. Ç. ve Salzınma, E. B. (1980). Amgı Tıva Literaturalıg Dıl. Kızıl: Tıvanın Nom Ündürer Çeri.

Suvan, Ş. (2009). Hemçik Noyanı. Kızıl: Tıvanın Nom Ündürer Çeri.

Tosun, İ. (2011). Tuva Türkçesinin Şekil Bilgisi. Basılmamış Doktora Tezi. Edirne: Trakya Üniversitesi.

TS 1 = Monguş, D. A. (2003). Tıva Dıldın Tayılbırlıg Slovarı C. 1. Novosibirsk: Nauka.

TS 2 = Monguş, D. A. (2011). Tıva Dıldı刀 Tayılbırlıg Slovarı C. 2. Novosibirsk: Nauka.

Turan, Ü. D. ve Durmuşoğlu Köse, G. (2011). Turkish Syntax, Semantics, Pragmatics and Discourse. Eskişehir: Anadolu Üniversitesi Yayını.

Usta, H. İ. (2009). “Kelime Gruplarını Nasıl Tasnif Edelim?” Uluslararası Türk Kültürü ve Edebiyat Kongresi, Türkçenin Söz Dizimi ve Üslup Çalışmaları, C. 1 (Ed. Hayati Develi), İstanbul: Kültür Üniversitesi.

Uzun, N. E. (2000). Anaçizgileriyle Evrensel Dilbilgisi ve Türkçe. İstanbul: Multilingual.

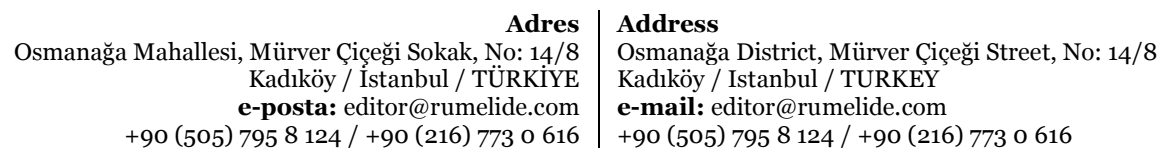


Üstünova, K. (2006). Yüklem, Yalnız Özneyi mi İçinde Taşır?. U.Ü. Fen-Edebiyat Fakültesi Sosyal Bilimler Dergisi. 7/11, 241-250.

Üstünova, K. (2007). "Yalın Durum Karmaşası". Turkish Studies Türkoloji Araştırmaları. 2/2 İlkbahar, 736-748.

Vardar, B. (2002). Açılamalı Dilbilim Sözlüğü. İstanbul: Multilingual. 